\title{
The Relationship with Ad Clicks and Purchase Intention: An Empiricial Study of Online Consumer Behaviour
}

Asoc. Prof. Şakir Erdem

Marmara University, Faculty of Business Administration, Istanbul

Prof. Dr. Beril Durmuş

Marmara University, Faculty of Business Administration, Istanbul

Osman Özdemir

Research Asisitant, Marmara University, Faculty of Business Administration, Istanbul

\begin{abstract}
This study examines the ads on social media and word of mouth marketing lead to ad clicks. Motivation, congruity, attitudes to ad on social media and word of mouth marketing lead to ad clicks, which respectively affect purchase intention in research model. The study aims to develop an understanding of how ad clicks affect to purchase intention on social media. Findings of the study presents the importance of consumer behaviour to use of social media and to purchase intention among Turkish consumers. Consequently, in the study all variables are positively related to each other. These results suggest that marketers need to take into account and manage actively social media and specifically their social network sites.
\end{abstract}

Keywords: Adclicks, Social Media, Purchase Intention, WOM, Consumption Motivation, Attitudes to Ads

\section{Introduction}

Consumers once had a limited number of media channels they obtained product information from word of mouth and print media to learn about products. Media channels increase in the 20th and 21st centuries and consumers could access information. Media contains all of the information anywhere, at any time after the advent of radio, television, internet and social media (Woo et al, 2015)

Especially social media affect to consumers' purchase intentions. Consumers' purchase intentions are driven by their perceived value. Word of mount affects the perceived value of goods or services. If consumers consider a product to be of high quality, they will show a higher willingness to buy it (Weisstein et al, 2014). Consumption motivation, congruity, attitudes to SNS advertising are important reasons to click ads on social media.

\section{Theoretical Background of Ad Clicks, WOM and Purchase Intention}

Tools and technologies for media and communication are undergoing major changes, based on economic transitions and digitisation (Pierson and Heyman). Especially, social media is commanding a larger share of advertising budgets, especially to reach the younger generation and affect their purchase intentions. It has become an imperative conduit for global marketing communications. Therefore, the value of advertising on social network sites such as Facebook, Youtube, Linkedln, Twitter and others is of great interest to companies, managers and academics (Saxena \& Khanna, 2013; Duffett, 2015).

Social media enable interactive information, user-created content and collaboration. It is classified social media by social presence and self-disclosure: personal blogs and micro-blogs, social networking sites, virtual worlds, collaborative projects and content communities (Kaplan and Haenlein, 2010). As consumers spend more time on social media, purchase decisions have become highly influenced by interactions through these networks. Thus, businesses are placing more emphasis on marketing strategies using two-way communication platforms to reach online consumers and take advantage of word-of-mouth (Song and Yoo, 2014; Heinrichs et al., 2011). 
Social network sites have a cognitive function in product choice. Customers prefer to be guided by information from friends and other personal contacts rather than a company's advertising department (Palmer and Lewis, 2009; Susskind, 2002; Harrison-Walker, 2001).

More than two-thirds of companies are using social media for marketing and service (Ma et al., 2015). Therefore, social media is exciting tool for marketers and managers. It has become preferred media all around the world and is influencing consumer behavior (Prasad, et al., 2017; Bernhardt et al., 2012). Social media has enabled people from anywhere to access companies any time through electronic devices, such as computers, mobile phones, etc. (Zhang and Mao, 2012)

Electronic devices are effective to click ads and purchase immediatedly as well. With the advance of the internet, through online advertising, companies communicate, interact with, and persuade online users in order to position a brand, which allows a company to promote both consumer awareness and preference in a customized and personalized way, and decrease the time needed to make a buying decision" (Hanafizadeh and Behboudi, 2012; Barreto, 2013). Furtermore, viral marketing uses by companies and defines marketing trend of the decade. Companies build awareness with viral campaigns and promote their products and services (Ferguson, 2008).

Word of mouth marketing has attracted both scholars and practitioners of marketing. It is investigated to understand its effect on companies and buying behavior, both online and offline (Brown et al., 2007). Especially, discussion forums, product reviews, emails and social network sites act as an source of information and opinions for WOM among consumers, serving as an important. These network sites have changed consumers to make purchase decisions, as they can easily and quickly exchange product-related information and opinions with personal contacts without geographic and time constraints (Kudeshia and Kumar, 2015; Graham and Havlena,2007).

\section{Congruity}

The congruency of advertisement, content and social network sites is important. Some kind of information that users do not look for when they visit these sites. Therefore, companies identify key consumers, generate content and prepare ads them to click ads and make purchase decision (Barreta, 20013) On the other hand, companies' web site congruity with stores, banks, social network sites and etc. should be easy. Nowadays alluring and confusing applications affect consumer purchase intentions (Cummins et al., 2014).

The relationship congruency and content on social network sites to consumer click ads and comment about companies (Chang and Fan, 2017). Especially, fan page can give rise to hedonic consumption through fan sites (Turel et al., 2010). On the other hand, children and younger people are under the environment effects (Gunter et al., 2002). Therefore, companies have to take in consideration the values of the children and younger people (Furnham and Price, 2006).

\section{Attitudes to Ads}

In the literature of advertising it has been proven that viewers show positive attitudes to informative ads on social networks. Entertaining ads also generate positive attitude towards company (Taylor et al.,2011) The entertaining nature of brandrelated contents influences people to read or watch and comment (Muntinga et al., 2011). Humour appeal in advertising does attract viewers (Khan, 2016). Attitudes to Ads can be defined as consumer's overall evaluation of an advertisement or company. The attitude of customer toward an advertisement has a significant effect on its purchase intention, as advertise attitude is the most important determinant of purchase intention (Kudeshia and Kumar, 2015; Olson and Mitchell, 2000). In recent years, social media has become a major factor in influencing various aspects of consumer behavior such as awareness, opinions, attitudes, purchase intention and post purchase communication and evaluation (Mangold and Faulds,2009). Since consumer accept and have a positive attitudes toward ads (Taylor et al., 2011), company ads should integrate with web site, forums, blogs, word-of-mouth forums and social network sites (Assimakopoulos et al., 2016).

\section{Consumption Motivation}

The information play the key role on consumption motivation. Information sharing is motivational factor affecting consumer's opinions. Therefore, these factors help companies that are planning to use a social network site in information sharing (Vuori and Okkonen, 2012). The basic motivations are the increasing popularity of social media, the congnizant of other companies's presence and low prices. Interact with companies, increasing new product awareness, payment by installments motivates consumer (Tsimonis and Dimitriadis, 2014). Consumer are motiveted with interactive ads strategies. The effectiveness of website and SNSs lead consumer to click ads (Rodgers et al., 2007). Motivation is positively connected 
with the loyalty of users. It motivates individuals to share knowledge in traditional way such as by word of month. Besides the engagement in information sharing on the internet or within social media channels motivate them. Social interaction with other users, such as posting, commenting and reviewing maintain relationships among members on SNSs.

\section{Conceptual Framework and Hypotheses}

Based on the previous research the following hypotheses have been listed to be tested.

$\mathrm{H}_{1}$ : Congruity has an effect on Ad Clicks

$\mathrm{H}_{2}$ : Attitudes to SNS Advertising has an effect on Ad Clicks

$\mathrm{H}_{3}$ : Consumption Motivation has an effect on Ad Clicks

$\mathrm{H}_{4}$ : WOM has an effect on Ad Clicks

$\mathrm{H}_{5}$ : Ad Clicks has an effect on Purchase Intention

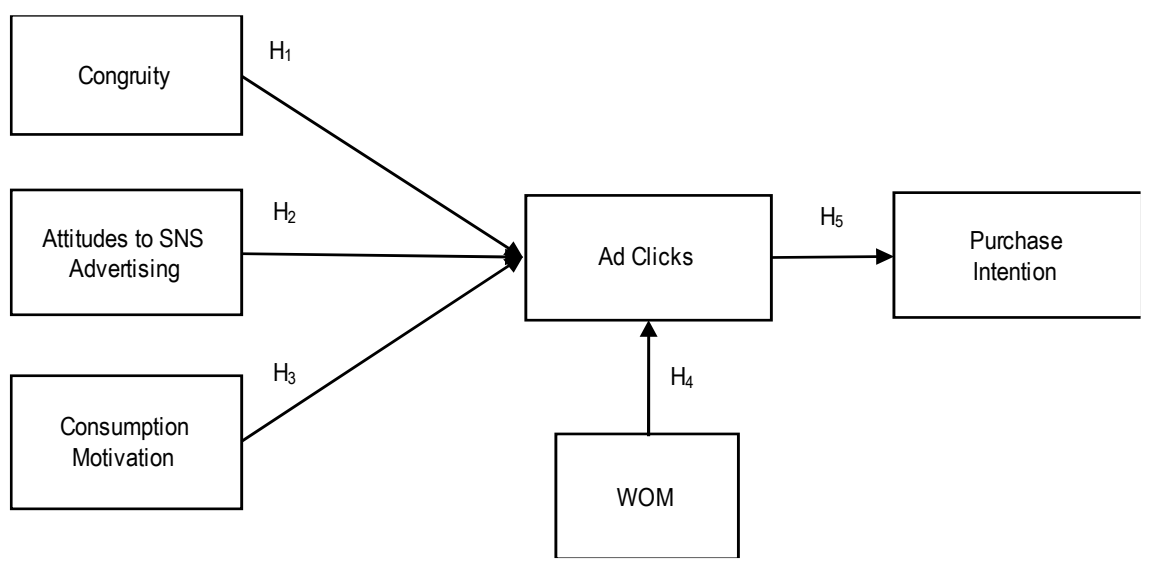

Figure 1. Conceptual Model

Based on these hypotheses, the research model is structured to explain how Congruity, Attitudes to SNS Advertising, Consumption Motivation and WOM affect Purchase Intention through Ad Clicks.

\section{Methodology}

\section{Measures}

A review of the literature yielded a number of measurement instruments that were employed to test the hypothesized model and each scale has a history of reliable measurement (See Table 2). All scales employed in this study were measured on five-point Likert scales ranging from 1 (strongly disagree) to 5 (strongly agree). In the process of translation, the techniques of back translation and parallel translation have been adopted with the help of a group of academicians fluent in English and Turkish. The final Turkish version of the questionnaire was further verified by the authors of this paper.

Table 1. Measurement items

\begin{tabular}{|l|l|l|l|}
\hline Construct & Item & Measurement & Reference \\
\hline Congruity & Congruity_1 & $\begin{array}{l}\text { While I browse SNS, I usually pay attention to the display ad } \\
\text { that matches the content I am browsing. }\end{array}$ & $\begin{array}{l}\text { Furnham and Price, 2006; } \\
\text { Gunter, Baluch, Duffy, and } \\
\text { Furnham, } \\
\text { 2002) }\end{array}$ \\
\hline & Congruity_2 & $\begin{array}{l}\text { While I browse SNS, I usually pay attention to the display ad } \\
\text { that relates to the content I am browsing. }\end{array}$ & \\
\hline
\end{tabular}




\begin{tabular}{|c|c|c|c|}
\hline & Congruity_3 & $\begin{array}{l}\text { While I browse SNS, I usually pay attention to the display ad } \\
\text { that fits well with the content I am browsing. }\end{array}$ & \\
\hline \multirow[t]{6}{*}{$\begin{array}{l}\text { Attitudes to SNS } \\
\text { Advertising }\end{array}$} & Attitude_towards_ads_1 & I like banner product and brand advertising on SNS profiles & \multirow[t]{6}{*}{$\begin{array}{l}\text { (Taylor et al., } \\
2011)\end{array}$} \\
\hline & Attitude_towards_ads_2 & $\begin{array}{l}\text { I like SNS profiles created by the sponsor company of the } \\
\text { product or brand. }\end{array}$ & \\
\hline & Attitude_towards_ads_3 & $\begin{array}{l}\text { I like SNS profiles created by customer/fans of the product or } \\
\text { brand. }\end{array}$ & \\
\hline & Attitude_towards_ads_4 & $\begin{array}{l}\text { I like YouTube videos created by the sponsor company of the } \\
\text { product or brand. }\end{array}$ & \\
\hline & Attitude_towards_ads_5 & $\begin{array}{l}\text { I like YouTube videos created by customers/fans of the } \\
\text { product or brand. }\end{array}$ & \\
\hline & Attitude_towards_ads_6 & I like Twitter feeds for the product or brand & \\
\hline \multirow{3}{*}{$\begin{array}{l}\text { Consumption } \\
\text { Motivation }\end{array}$} & $\begin{array}{l}\text { Consumption_ } \\
\text { Motivation_1 }\end{array}$ & I sometimes use SNS to make a purchase & \multirow{3}{*}{ (Rodgers et al, 2007) } \\
\hline & $\begin{array}{l}\text { Consumption } \\
\text { Motivation } 2\end{array}$ & I sometimes use SNS to buy things. & \\
\hline & $\begin{array}{l}\text { Consumption_ } \\
\text { Motivation_3 }\end{array}$ & $\begin{array}{l}\text { sometimes use SNS to purchase a product I have heard } \\
\text { about. }\end{array}$ & \\
\hline \multirow{3}{*}{ WOM } & WOM_1 & $\begin{array}{l}\text { recommend the brands shown in the display ads on SNS to } \\
\text { other people }\end{array}$ & \multirow{3}{*}{$\begin{array}{l}\text { (Ferguson, 2008; Turel } \\
\text { et al., 2010) }\end{array}$} \\
\hline & WOM_2 & $\begin{array}{l}\text { introduce the brands shown in the display ads on SNS to } \\
\text { other people. }\end{array}$ & \\
\hline & WOM_3 & $\begin{array}{l}\text { I say positive things about the brands shown in the display ads } \\
\text { on SNS to other people. }\end{array}$ & \\
\hline \multirow{3}{*}{ Ad Clicks } & Ad_Clicks_1 & I click on the display ads on SNS to understand more about & \multirow{3}{*}{ (Zhang and Mao, 2012) } \\
\hline & Ad_Clicks_2 & \multirow{2}{*}{$\begin{array}{l}\text { I click on the display ads on SNS to make a purchase. } \\
\text { I click on the display ads on SNS to get more information } \\
\text { about the products. }\end{array}$} & \\
\hline & Ad_Clicks_3 & & \\
\hline
\end{tabular}

Table 1. Measurement items (Continue)

\begin{tabular}{|l|l|l|l|}
\hline Purchase Intention & $\begin{array}{l}\text { Purchase__ intend to remain loyal to the brands shown in the display ads on } \\
\text { Intention_1 }\end{array}$ & $\begin{array}{l}\text { SNS in the future } \\
\text { Purchase__ } \\
\text { Intention_2 }\end{array}$ & $\begin{array}{l}\text { will not stop buying/supporting the brands shown in the display } \\
\text { ads on SNS. }\end{array}$ \\
\hline $\begin{array}{ll}\text { Purchase_ } \\
\text { Intention_3 }\end{array}$ & $\begin{array}{l}\text { I think of myself as a loyal consumer/supporter of the brands } \\
\text { shown in the display ads on SNS. }\end{array}$ & \\
\hline
\end{tabular}

\section{Sampling and Data Collection}

Data for this research was collected through a questionnaire survey. The survey screened the participants by asking whether they have used social media before. During six-week period, 350 respondents completed the survey. After sorting and removing duplicate submissions, a net sample of 333 usable questionnaires remained. The major demographics of the respondents were listed in Table 1. 
Table 2. Demographic characteristics of survey respondents ( $N=333$ )

\section{Demographic profile}

$\begin{array}{llll}\text { Gender } & \text { Female } & 168 & 50.5 \\ & \text { Male } & 165 & 49.5 \\ \text { Marital Status } & \text { Married } & 17 & 5.1 \\ & \text { Single } & 316 & 94.9 \\ \text { Education } & \text { High School } & 277 & 83.2 \\ & \text { University } & 48 & 14.4 \\ & \text { Graduate } & 7 & 2.1 \\ \text { Income } & \text { PhD } & 1 & 0.3 \\ & 0-1000 \mathrm{TL} & 194 & 58.3 \\ & 1001-2000 \mathrm{TL} & 72 & 21.6 \\ & 2001-3000 \mathrm{TL} & 25 & 7.5 \\ & 3001-4000 \mathrm{TL} & 19 & 5.7 \\ & 4001-5000 \mathrm{TL} & 13 & 3.9 \\ & \text { More than } 5001 \mathrm{TL} & 10 & 3.0\end{array}$

The sample comprised of 168 Female and 165 Male. Ages of the sample ranged between 18 to 46 with mean 22.12 standard deviation 3.70. Data obtained from questionnaires will be analyzed through the IBM SPSS 23.0 and AMOS statistical programs.

\section{Analysis and Findings}

The main purpose of the study is structured to explain how Congruity, Attitudes to SNS Advertising, Consumption Motivation and WOM affect Purchase Intention through Ad Clicks. To identify and test the underlying structure of the scales exploratory factor analyses (EFA) were employed to each measurement as the initial step. The EFA results were further validated with confirmatory factor analyses (CFA). Kaiser-Meyer-Olkin measure of sampling adequacy and Bartlett test of sphericity tests were performed to test the appropriateness of data for conducting factor analyses (Sharma, 1996)

Table 3. EFA and CFA results

\begin{tabular}{|c|c|c|c|c|}
\hline Constructs & EFA Loadings & $\begin{array}{l}\text { Cronbach's } \\
\text { Reliability }\end{array}$ & CFA Loadings & t value \\
\hline \multicolumn{5}{|c|}{$\begin{array}{l}\text { Congruity } \\
\left(\mathrm{KMO}=0.734, x^{2} \text { Bartlett test }(3)=691.410, p=0.000, V E=84.496, C R=0.910, A V E=0.772\right)\end{array}$} \\
\hline Congruity_2 & 0.941 & 0.906 & 0.934 & $25.072^{\star \star \star}$ \\
\hline Congruity_1 & 0.926 & & 0.897 & a \\
\hline Congruity_3 & 0.890 & & 0.800 & $19.148^{* \star *}$ \\
\hline \multicolumn{5}{|c|}{$\begin{array}{l}\text { Attitudes to SNS Advertising } \\
\left.\text { (KMO }=0.790, x^{2} \text { Bartlett test }(10)=825.558, p=0.000, V E=64.512 C R=0.863 \text { AVE }=0.559\right)\end{array}$} \\
\hline Attitude_towards_ads_2 & 0.835 & 0.861 & 0.786 & $11.960^{\star \star \star}$ \\
\hline Attitude_towards_ads_3 & 0.827 & & 0.776 & $11.844^{\star \star \star}$ \\
\hline Attitude_towards_ads_4 & 0.823 & & 0.766 & $11.728^{* \star *}$ \\
\hline Attitude_towards_ads_5 & 0.798 & & 0.750 & $11.543^{\star \star \star}$ \\
\hline Attitude_towards_ads_1 & 0.729 & & 0.653 & a \\
\hline \multicolumn{5}{|c|}{$\begin{array}{l}\text { Consumption Motivation } \\
\text { (KMO }=0.500, x^{2} \text { Bartlett test }(1)=343.036, p=0.000, V E=90.181 \mathrm{CR}=0.891, \mathrm{AVE}=0.804 \text { ) }\end{array}$} \\
\hline Consumption_Motivation_3 & 0.950 & 0.891 & 0.915 & $15.008^{\star \star \star}$ \\
\hline Consumption_Motivation_2 & 0.950 & & 0.878 & a \\
\hline \multicolumn{5}{|c|}{$\begin{array}{l}\text { WOM } \\
\text { (KMO }=0.767, x^{2} \text { Bartlett test }(3)=811.425, p=0.000, V E=87.964 C R=0.931, A V E=0.819 \text { ) }\end{array}$} \\
\hline WOM_2 & 0.941 & 0.932 & 0.921 & 26.107 \\
\hline WOM_3 & 0.939 & & 0.901 & 24.863 \\
\hline WOM_1 & 0.933 & & 0.893 & a \\
\hline
\end{tabular}




\begin{tabular}{|c|c|c|c|c|}
\hline $\begin{array}{l}\text { Ad Clicks } \\
(\mathrm{KMO}=0.83\end{array}$ & $.000, \mathrm{~V}$ & $29 \mathrm{CR}=$ & $=0.635$ & \\
\hline Ad_Clicks_3 & 0.878 & 0.839 & 0.823 & $15.063^{* * *}$ \\
\hline Ad_Clicks_1 & 0.868 & & 0.785 & a \\
\hline Ad_Clicks_2 & 0.863 & & 0.782 & $14.334^{\star * \star}$ \\
\hline
\end{tabular}

\section{Purchase Intention}

(KMO $=0.754, x^{2}$ Bartlett test $(3)=703.432, p=0.000, V E=85.472$ CR=0.915, AVE=0.919)

$\begin{array}{llllr}\text { Purchase_Intention_2 } & 0.938 & 0.914 & 0.911 & 22.132^{* * *} \\ \text { Purchase_Intention_3 } & 0.920 & 0.894 & 21.440^{* * *} \\ \text { Purchase_Intention_1 } & 0.916 & 0.846 & a \\ x^{2}(137, N=333)=356.960, p=0.000 ; \text { GFI=0.896, NFI=0.929, CFI=0.955, TLI=0.944, RMSEA=0.07 }\end{array}$

$V E=$ Variance Explained; $C R=$ Construct Reliability; AVE=Average variance extracted; ${ }^{* * *} p<0.000$

Results of the tests were satisfactory. Principal Component Factoring and Varimax rotation were employed to the data set. Factors with eigenvalues over one were retained and items with factor loadings below 0.50 and items with high cross loadings were excluded (Hair et. al., 2006).

As can be seen from Table 3., reliabilities for factors were 0.500 and 0.839 respectively. EFA results of Congruity, Attitudes to SNS Advertising, Consumption Motivation, WOM, Ad Clicks and Purchase Intention showed that all six scales were unidimentional as expected. Reliabilities for each construct were $0.734,0.790,0.500,0.767$ and 0.839 respectively. To test the internal consistency of factors, Cronbach's coefficient alpha reliabilities were estimated. As it is shown the reliability measures of constructs ranged from 0.839 to 0.931 , which shows satisfactory levels of internal consistency (See Table 3).

Then confirmatory factor analyses (CFA) were conducted using IBM SPSS AMOS 23.0 program to validate the factors proposed by EFAs. Chi-square test statistics are usually quite sensitive to sample size (Hair et. al. 2006), therefore in this study; Goodness of Fit Index (GFI), Comparative Fit Index (CFI), Normed Fit Index (NFI), Tucker Lewis Index (TLI) and Root Mean Square Error Approximation (RMSEA) were considered.

Results of EFA and CFA for each construct are explained below. The procedures to check for convergent validity and discriminant validity were practiced (Anderson and Gerbing, 1988; Fornell and Larcker, 1981). Construct reliabilities of $0.910,0.863,0.891,0.931,0.839$, and 0.915 indicated high internal consistency of the dimensions (Hair et al. 2006; Netemeyer et al. 2003). Average variance extracted (AVE) values, which reflect the overall amount of variance accounted for by the latent constructs, were all above 0.50 threshold; AVEs ranged between 0.559 to 0.919 (Fornell and Larcker 1981). Items under each construct, factor loadings, Cronbach's alpha and construct reliabilities are given in Table 3. The various fit indices for the CFA suggested good fit to the data $x^{2}(137, N=333)=356.960, p=0.000$, Goodness of Fit Index $(\mathrm{GFI})=0.896$, Comparative Fit Index $(\mathrm{CFI})=0.955$, Normed Fit Index $(\mathrm{NFI})=0.929$, Tucker-Lewis Index $(\mathrm{TLI})=0.944$, Root Mean Square Error Approximation (RMSEA) $=0.07$ ).

There is no standard for acceptable GFI, but rule of thumb is GFI greater than 0.90 (Lattin et al., 2003) and RMSEA values of 0.08 and less have been advocated as indicative of acceptable fit (Hu and Bentler 1999; Lattin et al., 2003). Consequently, goodness of fit indexes supported the proposed model as fit.

\section{Structural Model}

Since the objective of this study was to identify dimensions that increased Intention to shop online, a structural model was tested. The result of the path analysis showed a good fit of the model $\left(x^{2}(143)=381.595, p=0.00 ; G F I=0.903, C F I=0.936\right.$, $\mathrm{NFI}=0.903, \mathrm{TLI}=0.957, \mathrm{RMSEA}=0.068$ ). 


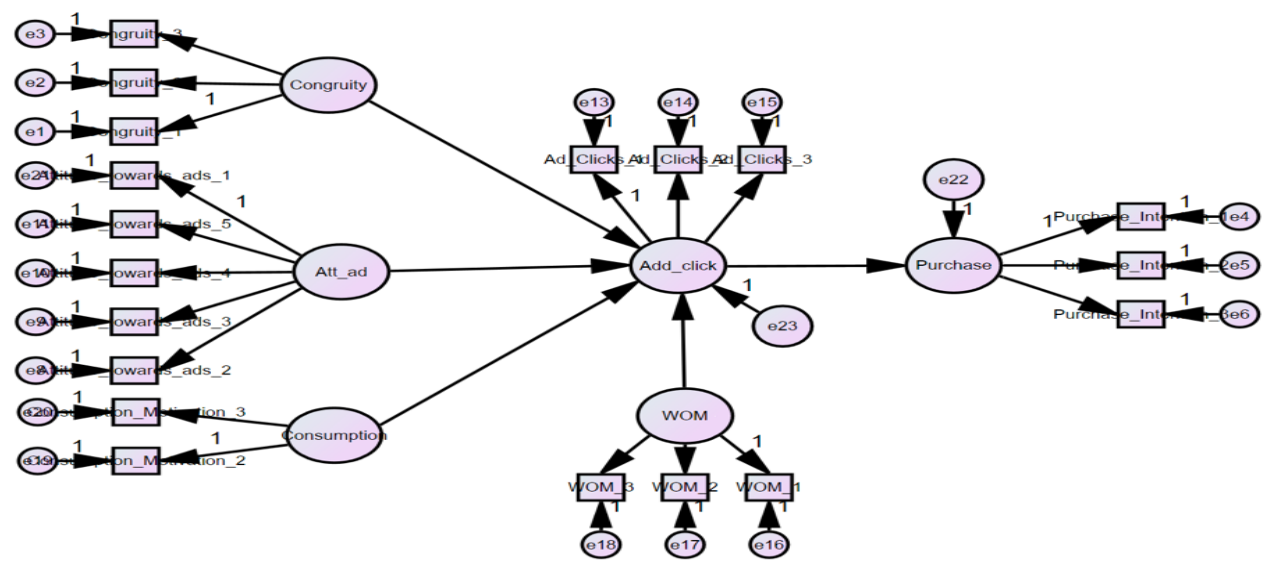

Figure 2. Graphical representation of path model

Table 4. Result of Path Analysis

$\begin{array}{lll}\text { Paths } & \text { Standardized path coefficient } & \text { t value } \\ \text { Congruity } \square \text { Ad Clicks } & 0.134 & 2.829^{*} \\ \text { Attitudes to SNS Advertising } \square \text { Ad Clicks } & 0.152 & 2.873^{*} \\ \text { Consumption Motivation } \square \text { Ad Clicks } & 0.095 & 2.277^{*} \\ \text { WOM } \square \text { Ad Clicks } & 0.803 & 10.246^{* * *} \\ \text { Ad Clicks } \square \text { Purchase Intention } & 0.863 & 10.680^{* *}\end{array}$

$x^{2}(136)=332.395, p=0.000 ; \mathrm{GFI}=0.907, \mathrm{CFI}=0.960, \mathrm{NFI}=0.934, \mathrm{TLI}=0.949, \mathrm{RMSEA}=0.066$

${ }^{*} p<0.05 ;{ }^{* *} p<0.01^{* * *} ; p<0.001$

As a result of the path analysis it was found that the Congruity, Attitudes to SNS Advertising, Consumption Motivation and WOM affect Purchase Intention through Ad Clicks.

\section{Conclusion}

The paper finds that congruity, attitudes to ads and consumption motivation are efficient to click ads. Word of mount marketing lead to ad clicks, which respectively affect to purchase intention aswell. The importance of consumer behaviour and advertising on SNSs such as Facebook, Youtube, Linkedln, Twitter and others come to exist in the study. Companies reserve a share of advertising budgets, especially to reach the chiildren and younger generation and affect their purchase intentions. Consequently, in the study all variables are positively related to each other and shows satisfactory levels. These results suggest that marketers need to take into account and manage actively social media and specifically their social network sites.

\section{References}

[1] Ana Margarida Barreto, (2013) "Do users look at banner ads on Facebook?", Journal of Research in Interactive Marketing, Vol. 7 Issue: 2, pp.119-139.

[2] Anderson, J. C. \& Gerbing, D. W. (1988). Structural equation Modeling in Practice: A Review and Recommended Two-Step Approach. Psychological Bulletin 103(May): 411-423.

[3] Bernhardt, J.M., Mays, D. and Hall, A. K. (2012), "Social marketing at the right place and right time with new media", Journal of Social Marketing, Vol. 2 No. 2, pp. 130-137. 
[4] Brown, J., Broderick, A.J. and Lee, N. (2007), "Word of mouth communication within online communities: conceptualizing the online social network", Journal of Interactive Marketing, Vol.21No.3, pp.2-20.

[5] Chetna Kudeshia, Amresh Kumar, (2017) "Social eWOM: does it affect the brand attitude and purchase intention of brands?", Management Research Review, Vol.40, 3, 310-330

[6] Fei Lee Weisstein, Mohammadreza Asgari, Shir-Way Siew, (2014) "Price presentation effects on green purchase intentions", Journal of Product \& Brand Management, Vol.23, 3, 230-239.

[7] Ferguson, R. J. (2008). Word of mouth and viral marketing: Taking the temperature of the hottest trends in marketing. Journal of Consumer Marketing, 25, 179-182.

[8] Fornell, C. \& Larcker F. D. (1981). Evaluating Structural Equation Models with Unobservable Variables and Measurement Error. Journal of Marketing Research Vol:18, 39-50.

[9] Furnham, A., \& Price, M.-T. (2006). Memory for televised advertisements as a function of program context, viewer involvement, and gender. Communications, 31, 155-172.

[10] Georgios Tsimonis, Sergios Dimitriadis, (2014) "Brand strategies in social media", Marketing Intelligence \& Planning, Vol. 32 Issue: 3, pp.328-344.

[11] Graham, J.and Havlena, W. (2007), "Finding the missing link":advertising's impact on Word of mouth, web searches, and site visits", Journal of Advertising Research, Vol. 47 No. 4, 427-435

[12] Gunter, B., Baluch, B., Duffy, L. J., \& Furnham, A. (2002). Children's memory for television advertising: Effects of programme-advertisement congruency. Applied Cognitive Psychology, 16, 171-190

[13] Hair Jr. F. J., Black C. W., Babin J. B., Anderson E. R., \& Tatham L. R. (2006). Multivariate Data Analysis. Upper Saddle River, NJ: Prentice Hall Inc.

[14] Hanafizadeh, P. and Behboudi, M. (2012), Online Advertising and Promotion: Modern Technologies for Marketing, IGI Global, Hershey, PA.

[15] Heinrichs, J.H., Lim, J.S.and Lim, K.S. (2011),"Influence of social networking site and user access method on social media evaluation", Journal of Consumer Behaviour, Vol.10, No.1, 347-355

[16] Hu, L.T. and Bentler, P.M. (1999). Cutoff Criteria for Fit Indexes in Covariance Structure Analysis: Conventional Criteria Versus New Alternatives, Structural Equation Modeling, Vol. 6, No.1, 1-55.

[17] Imran Khan, Han Dongping, Akhter Wahab, (2016) "Does culture matter in effectiveness of social media marketing strategy? An investigation of brand fan pages", Aslib Journal of Information Management, Vol. 68 Issue: 6, pp.694-715.

[18] Jo Pierson, Rob Heyman, (2011) "Social media and cookies: challenges for online privacy", info, Vol. 13 Issue: 6, pp.30-42.

[19] JongRoul Woo, Joongha Ahn, Jongsu Lee, Yoonmo Koo, (2015) "Media channels and consumer purchasing decisions", Industrial Management \& Data Systems, Vol. 115 Issue: 8, pp.1510-1528.

[20] Kaplan enable, A. M. and Haenlein, M. (2010), "Users of the world, unite the challenges and opportunities of social media", Business Horizons, Vol. 53 No. 1, p. 59.

[21] Lattin, J.M., Carroll, J.D. \& Green P.E. (2003). Analyzing Multivariate Data, Duxbury applied series, Thomson Brooks/Cole.

[22] Ma, L., Sun, B. and Kekre, S. (2015), "The squeaky wheel gets the grease-an empirical analysis of customer voice and firm intervention on Twitter", Marketing Science, Vol.34 No.5,627-645.

[23] Muntinga, D. G., Moorman, M.and Smit, E. G. (2011),"Introducing COBRAs", International Journal of Advertising, Vol. 30 No. 1, pp. 13-46. 
[24] Naik, P.A. and Peters, K. (2009), "A hierarchical marketing communications model of online and offline media synergies", Journal of Interactive Marketing, Vol. 23 No. 4, pp. 288-299.

[25] Netemeyer, R., G. Bearden, W. O. \& Sharma, S. (2003). Scaling Procedures: Issues and Applications. Thousand Oaks, CA: Sage Publication.

[26] Rodgers, S., Wang, Y., Rettie, R. \& Alpert, F. (2007). The web motivation inventory: Replication, extension and application to internet advertising. International Journal of Advertising, 26, 4, 447-476.

[27] Rodney Graeme Duffett, (2015) "Facebook advertising's influence on intention-to-purchase and purchase amongst Millennials", Internet Research, Vol. 25 Issue: 4, pp.498-526.

[28] Saxena, A. and Khanna, U. (2013), "Advertising on social network sites: a structural equation modelling approach", Vision, Vol. 17 No. 1, pp. 17-25.

[29] Shantanu Prasad, Ishwar C. Gupta, Navindra K. Totala, (2017) "Social media usage, electronic word of mouth and purchase-decision involvement", Asia-Pacific Journal of Business Administration, Vol. 9 Issue: 2, pp.134145.

[30] Shing-Wan Chang, Shih-Heng Fan, (2017) "Cultivating the brand-customer relationship in Facebook fan pages: A study of fast-fashion industry", International Journal of Retail \& Distribution Management, Vol. 45 Issue: 3, pp.253-270.

[31] Sujin Song, Myongjee Yoo, (2016) "The role of social media during the pre-purchasing stage", Journal of Hospitality and Tourism Technology, Vol. 7 Issue: 1, pp.84-99.

[32] Taylor, D.G., Lewin, J.E. and Strutton, D. (2011), "Friends, fans, and followers: do ads work on social networks?", Journal of Advertising Research, Vol. 51 No. 1, pp. 258-275.

[33] Taylor,D.,Lewin,J.,\&Strutton,D.(2011).Friends,fans, and followers: Do ads work on social networks? How gender and age shape receptivity.Journal of Advertising Research,51,258-275

[34] Turel, O., Serenko, A., \& Bontis, N. (2010). User acceptance of hedonic digital artifacts: A theory of consumption values perspective. Information \& Management, 47, 53-59

[35] Zhang, J., \& Mao, E. (2012). What's around me? Applying the theory of consumption values to understanding the use of location-based services (Ibs) on smart phones. International Journal of E-Business Research 8, 3349. 